\title{
AGRICULTURAL DYNAMICS IN PAKISTAN: CURRENT ISSUES AND SOLUTIONS
}

\author{
Fawad Zafar Ahmad Khan ${ }^{1}$, Muhammad Sagheer ${ }^{1}$, Mansoor ul Hasan ${ }^{1}$, \\ Hafiza Tahira Gul ${ }^{2}$, Feehan Hassan ${ }^{1}$, Syed Amir Manzoor ${ }^{3}$, Atif Wahid ${ }^{2}$, Researchers \\ ${ }^{1}$ University of Agriculture, Faisalabad, Pakistan. \\ ${ }^{2}$ Bahauddin Zakariya University, Multan, Pakistan \\ ${ }^{3}$ PMAS-Arid Agriculture University, Rawalpindi, Pakistan \\ E-mail: amir.kzd@gmail.com
}

\begin{abstract}
Agriculture is heavily contributing towards the economy of Pakistan. Water deficiency and drought conditions, long duration load shedding issue, poor extension services, absence of land reforms, absence of distribution of certified varieties, high price of fertilizers, deliberate use of adulterated, non-recommended and expired insecticides, non utilization of cultivable waste land, conventional farming practices, indirect access of farmer to main market, absence of ecological based cropping pattern, smuggling of agricultural inputs and outputs, lack of cooperation between agricultural research, education \& extension services, absence of crop insurance, depletion of forests, lack of modern post-harvest technologies and disease outbreaks of poultry birds are some of the key issues that are playing a negative role in demotion of agricultural sector in Pakistan. The review article will briefly discuss above mentioned issues and some of the possible remedies under the environment of Pakistanand their adoption to improve the agricultural productivity in the country.
\end{abstract}

\section{KEY WORDS}

Agriculture; Pakistan; Issues.

Pakistan is an agricultural based country and out of 80 Mha of the total land, 22 Mha is being utilized for the agricultural production. Significant increase in the cropping area has been observed over the last three decade as the cropping area increased from 16.62 Mha to 22.15 Mha during the period of 1971 to 2003 but due to the rapid increase in the population, per capita land availability has drastically decreased. The projected annual growth rate is depicting a worse picture in the near future with respect to agricultural economy. Economy of the country is resting on the shoulders of agriculture sector. With a contribution of $21 \%$ in GDP and employment of more than $48.4 \%$ of the total working force, this sector is the biggest contributor in the economy of the country. Cropping sector has $60 \%$ of the total agriculture contribution to the GDP while the livestock and forestry accounts for $40 \%$ (Government of Pakistan, 2011). Agriculture sector in Pakistan is also facing some of the most serious issues and there is a need to highlight and solve these issues at first priority.

\section{AGRICULTURAL ISSUES IN PAKISTAN}

Following are some of the key issues and problems that have worse effects on agriculture and ultimately the economy of Pakistan.

Water deficiency and drought conditions. Pakistan, a country once a water-surplus country, is now gaining attention as a water-deficit country (Kahlown and Majeed, 2003). Indus River is also called as the backbone of Pakistan's economy mainly due to provision of $90 \%$ of the water contribution towards agriculture sector. Like other developing countries of the world the population of Pakistan is also growing at a faster pace and according to the projected population estimate the population of the country will rise to 250 Million by 2025 which will ultimately drop down the per capita availability of water (Bhutta, 1999). The controversial Baglihar Dam and possible shortfall (32\%) can induce a great drop in food production and a shortage of 70 Million tons of food is expected following 2025 (ADB, 2002). It is one of the biggest issues for the agriculture of Pakistan. 
Long duration load shedding. Load shedding is counted among some of serious threats to agriculture. There is an increasing loads heeding with the passage of time. More than $1,075,073$ tube wells (Government of Pakistan. 2011) are irrigating the land and due to the serious electricity short fall, these fail to work in an optimum manner. Diesel is an alternate to run these tube wells but the higher diesel prices have posed another problem to the farmers of the country. Unannounced load shedding can disturb the sowing of different crops (Daily Nation, 2008).

Poor extension services. Agricultural extension is one of the driving forces that are responsible for the growth of agricultural productivity by transferring latest and improved technologies to the farmers and ultimately strengthens the national economy (Sadaf et al., 2005). Unfortunately, the developing countries are failing to transfer the technology to farmer level (Government of Malawi, 2000) and it is getting worse with the passage of time (Eicher, 2001). Out dated traditional extension services are unable to fulfill the demands posed by modern crop production and protection (World Bank, 2002; Obaa et al., 2005).

Absence of land reforms. Land reforms refer to the government backed changing in the law and regulations for the transfer of ownership of agricultural land evenly in the whole state (Kinsey, 1999). Due to the absence of the land reforms in Pakistan the subsidies and other farmer based incentives given by the government are enjoyed by the landlords and the farmer with small land holding suffers in the end (Haq, 2012). About 2 percent of households has a complete hold on the 45 percent of the land area. Progressive and politically influenced farmers have also taken advantage of government subsidies in agriculture and water sectors, and benefited from technological improvements which have boosted yields on their large farms while the small farmer is unable to enjoy these benefits (World Bank, 2003). Absence of the land reforms is also bringing about negative changes in the society and is resulting in an over increasing rate of poverty and consequently there is an increased rate of the negative behavior in society (IRINEWS, 2009).

Absence of distribution network for quality seed. Poor quality seed has a major effect on the germination as well as the overall vigor of the plant especially in the case of wheat (Barnarda and Calitz, 2011) which is considered as the staple food in Pakistan. Provincial Seed Corporations are intended to distribute the quality seed. Due to the limited level availability of certified seed, misguidance by many local seed distributors and low quality seed the agriculture sector is suffering from low production per unit area. Availability of poor quality seed is one of the major problems in modern agricultural context in Pakistan (Alam and Naqvi, 2003).

High price of fertilizers and monopoly of companies. High prices of the fertilizers are mainly due to the increase in the prices of the natural gas and monopoly of the fertilizer companies working in Pakistan. Increased General Sales Tax on the natural gas is also one of the reasons for this hike in the prices (Daily Nation, 2012). The increase in the gas prices has a direct effect on the per bag price of every fertilizer especially urea which is being deliberately used in the agricultural sector (Dawn, 2013). Due to the increase in the prices of these fertilizers an average farmer fails to give his best on the farm and in turn low yield cause the financial pressure and other problems (FAO, 2004). As high as $2.5 \$$ increase per bag of urea is expected by the peak season in 2013 which will be overall discouraging for the farming community in Pakistan (BLACKSEAGRAIN, 2013).

Use of adulterated or expired insecticides. Although government has claimed that it has controlled the pesticide adulteration and decreased it to $1 \%$ but there is a continuous trend of using low quality insecticides (Daily Times, 2012) Poor quality insecticides affect the environment and also induce some of the serious health issues due to their prolonged residual effects (Jabbar and Mallick, 1994). Moreover, during the peak season there has been a shortage of the good quality insecticides and the market is dominated by the business of the adulterated or expired insecticides which in turn are detrimental for the overall economic progress and the sustainable agriculture in Pakistan (Dawn, 2013).

Non utilization of cultivable waste land. Cultivable waste land accounts for a greater percentage of the total agricultural land in Pakistan. As the increase in population is very rapid, consequently per capita availability of land is decreasing mainly due to the non 
utilization of the cultivable wastelands of Baluchistan(Bhutta, 1999). Government of Pakistan took a step towards the provision of the cultivable waste land to the students that are related to agriculture sector but the land holding groups didn't permit the government to precede the project (Soomro, 2011)

Conventional farming practices. Conventional farming practices have an owner yield as compared to the modern practices. It is perhaps a great hurdle to replace the conventional methods with modern ones (Feder, 1985). He traditional practices are more common in the developing countries like Pakistan and these practices are mainly due to the smaller farm size as the small level peasant is unable to bear the farm expenses and result in low yield per unit area (Khwaja, 2013).

Indirect access of farmer to main market. Middlemen intervention is one of the biggest hurdles to improve the socio economic status of the small land holders (Khan, 2010). For this reason the farmer fails to get the real price of his hard work and inputs. Small peasants are unable to access the market and get the rate that is the original price of the commodity (Malik et al, 1989)

Absence of ecological based specialized cropping belts. Every geographical location has a perfect environment for the production of a specific agricultural commodity. Many parts of Pakistan are not getting the optimum production mainly due to the absence of this strategy (Qureshi, 2012, Manzoor et al., 2013, Asim et al., 2013).

Deliberate smuggling of agricultural products. Among the crops, wheat (Pakkissan, 2005) and rice (Pakkissan 2007), while among fertilizers, urea (Tribune, 2011) is smuggled more as compared to any other agricultural produce. Due to the war in Afghanistan, this problem has drastically increased and disturbing the agricultural sector.

Non cooperation between modern research and extension. Flow of latest research to the farmer is not immediate mainly due to the non cooperation of the extension and research departments working separately in Pakistan (Kyomo, 2006).

Absence of organzied crop insurance policy. In case of any loss due to heavy insect attack, disease outbreak, floods, fires, etc. there is no insurance plan for the small land holders. The farmer suffers due to these losses and ultimately, agriculture suffers.

Lack of modern post harvest technologies. The post harvest losses are major influencing factors that determine the final production of a country. Pakistan is facing heavy post harvest loss due to poor infrastructure, lack of modern storage facilities, limitation of processing units and slow transportation (Shah and Farooq, 2000)

Depletion of forests. Area of forest is decreasing due to due to an annual (2011-12) contribution of more than 92,000 Cubic meters (Government of Pakistan, 2012). Due to increase in the deforestation, there has been a progressive increase in the process of Erosion and flood losses are expected to increase in the coming months.

Disease outbreaks of poultry birds. New Castle poultry disease and Bird flu disease are counted among the most lethal disease that infects whole population in a very short period of time (The News, 2012).These diseases are contributing to the lower yield of per capita availability of protein.

\section{REMEDIES/SOLUTIONS FOR AGRICULTURAL ISSUES IN PAKISTAN}

In view of the above mentioned critical issues, following are possible remedies in the Pakistani perspective.

Construction of dams. Construction of a big dam like Kala Bagh Dam is the only solution towards a long term support to agricultural sector. Small projects like Gomal Zam Dam (Khyber Pakhtunkhwa), Greater Thal Canal (Punjab), Rainee Canal (Sindh), Kachhi Canal (Balochistan), Raising of Mangla Dam (AJ\&K), Satpara Dam (Skardu) and Right Bank Outfall Drain (RBOD) are some of the current projects that are under construction and may add some part in solving this issue (Government of Pakistan, 2012)

Nuclear power plants. Pakistan, being a nuclear state, has a capability to produce the nuclear powered electricity. The recent development is coming due to the cooperation of 
China in the making of two nuclear power plants that are expected to work at the end of 2016. Each power plant will produce electricity of 340 MW (Pakistan Today, 2013)

Privatization of extension in Pakistan. Extension in developing countries has proved to be ineffective and lack many active aspects (Tilman et al, 2002). So, Privatization of extension services seems to be a perfect solution and will ultimately lead to a cost-effective demand-driven system that will bring about the efficient and quality agricultural production all across the country. The best example of privatization can be seen in the pesticide sector in which there are more than 320 companies operating in Punjab, Pakistan. These companies not only provide the information about the pesticides but also have a well established advisory service for general learning of farmers (Shoukat, 2009).

Implementation of justice based land reforms. Land reforms, perhaps, seems to be the key element in the reduction of poverty and empowerment of the poor farmers having small land holdings. Landless farmers should be given the opportunity to improve their social status. A great political and judicial intervention is needed so as to overcome to fight against the feudalist system prevailing across the country (Naeem, 2012).

Commercialization of certified seed at subsidized rates. Government of Pakistan should take a strong initiative towards the marketing and commercialization of certified seed according to different area and local cropping scheme prevailing in that particular area. The federal seed certification authority should be given the authority to market the seed at the grass root level.

Natural gas availability to fertilizer sector. Natural gas is the only raw material that is utilized in the fertilizer industry and there is a need for the supply of subsidized gas to the fertilizer sector. The demand of the fertilizer companies is the provision of uninterrupted gas supply in order to cut down the prices per bag of fertilizers (Tribune, 2012). Recent success of Iran Pak Gas Pipeline Project will further facilitate the natural gas demand by the fertilizer industry (The News, 2013)

Reforms of pest warning and quarantine department. As there is a definite impact of overuse of low quality pesticides on environment and human health (Sheikh et al, 2011), so there is a need to reform the pest warning and quarantine department by increasing the authorities above any of the political influences. These reforms should cover all levels up to the Village level so as to facilitate the small farmers.

Water supply plan for Balochistan. Water desalinization plants (powered by the electricity harvested from solar panel network) across the province can decrease the issue of non availability of water and consequently the cultivable wasteland will reclaim in a shorter period of time (Shehzad, 2012). This will bring more cultivable land under use and more than $40 \%$ of the area will come under cultivation and consequently, productivity per unit area will increase.

Promotion of research based farming. Research based farming practices will enhance the agricultural production. For this purpose government should give greater amount of subsidy as compared to the present subsidy of 21 Billion on fertilizers and agricultural machinery (Pathan, 2007). Modern farming practices have a definite impact on the productivity and the farmers should adopt but this is never possible without the involvement of government.

Discouragment of middlemen interference. Role of middlemen should be discouraged so as to encourage the farming community at the grass root level. In this way the low level farmer will get the best price and the economic condition of the country will improve (Khan, 2010)

Promotion of ecological zone based cropping system. Government is now taking interest in Zone strategies and initially declared Potohar as Olive Zone, Cholistan as Grape Zone and Layyah/Bakhar as Citrus Zone (Ahmad, 2012). This will increase the overall productivity per unit area mainly due to the suitability of the environment related to the overall production.

Controlling smuggling of agricultural products. Intervention of border forces and security checks across the country can help controlling this issue (Tribune, 2013). Now the government of Pakistan is also taking some of the serious actions towards the cross border 
movement of the agricultural commodities especially wheat so as to increase the availability at consistent price levels (Dawn, 2013)

Strengthening research-extension bond. After the privatization of the extension department, the next step should be the integration of the department with different research institutes and universities. The students should be given the cultivable wasteland and they should be given a target. Performance based farming based on the new research should be promoted and incentives should be given to those farmers who perform and get higher yields by the adoption of new technology.

Crop insurance policy for small land holdes. Crop insurance should be provided to the small land holders for decreasing poverty and improving the socioeconomic status of farmer. The crop insurance policy is very important as it will give a security to the farmer but this policy will fail if the government fails to subsidize the rates of fertilizers and pesticides.

Introduction of modern post harvest technologies. Modern post harvest technologies should be provided to reduce the post harvest losses in horticultural crops as well as in fisheries (The NEWS, 2012). Storage technologies should be reformed to store the grains and other agricultural commodities for a greater period of time. For this purpose, the success stories of the progressing nations should be followed.

Reforestation. Special community based incentives should be offered in effort to induce reforestation movement in the country. Mass forestation campaigns should be launched at national level involving the academia and the farming community. Biannual farming campaigns and incentives for the perennial farmers will increase the forest area in Pakistan. This will be helpful in longer term and in the province of Sindh to avoid the threat of expected floods all over the country in the coming decade.

Promoting controlled environment sheds. Controlled environment sheds should be subsidized by the government to help the farmers shift from conventional sheds to modern sheds. Poultry vaccines and other medicines should be available so as to avoid some of the serious disease in this poultry sector. Farmers should be educated for the importance of control sheds and subsidy should be given on the raw material and equipment required to build these advanced structures.

\section{CONCLUSION}

Pakistan is a agro based country and the problems related to this major sector pose threats to the overall economy and the strategic situation. In long term context, the present situation is alarming because of the lack of interest of higher authorities towards this important sector. Adopting the practical suggestions given in this review will definitely increase the Agricultural GDP of Pakistan.

\section{REFERENCES}

[1] A. Barnard and F.J. Calitz, 2011, The effect of poor quality seed and various levels of grading factors on the germination, emergence and yield of wheat. South Afric. J. Plant Soil. 28(1):56-59.

[2] ADB 2002.: Water resources strategy study. Report Vol. 1, Islamabad, Pakistan.

[3] Adeel Pathan, 2007. Govt providing Rs21bn subsidy to agriculture. Website Link http://www.pakissan.com/english/news/newsDetail.php?newsid=15115.

[4] Ahmad, N. 1999. Fertilizer scenario in Pakistan: policies and development. In: Proc. Conference on Agriculture and Fertilizer Use by 2010. NFDC Publication 2/99. Islamabad.

[5] Ahmed, Q. 2012. Conventional farming leading to low citrus yield.

[6] Alam, S.M. and M.H. Naqvi. 2003. The gap between supply and demand of agricultural

[7] Anonymous, 2011. Pakistan Economic Survey 2011-12. Ministry of Finance, Islamabad. 
[8] Bhutta, M.N, 1999. Vision on Water for Food and Agriculture: Pakistan Perspective: Regional South Asia Meeting on Water for Food and Rural Development, New Delhi, June 13, 1999.

[9] BLACKSEAGRAIN, 2013.Pakistan. Urea price may go up by Rs 250 per bag. http://www.blackseagrain.net/data/news/pakistan.-urea-price-may-go-up-by-rs-250-perbag.

[10] Daily Nation, 2008. Load shedding hits agriculture sector of Pakistan. Website link: http://www.nation.com.pk/pakistan-news-newspaper-daily-english-online/business/15Oct-2008/Loadshedding-hits-agriculture-sector.

[11] Daily Times, $2010 . \quad$ Website Link: http://www.dailytimes.com.pk/default.asp?page $=2010 \% 5$ C07\%5C07\%5Cstory7-7$2010 p g 136$.

[12] Dawn, 2013. Fertiliser sector Raise in gas prices to hit farmers. http://beta.dawn.com/news/812724/fertiliser-sector-raise-in-gas-prices-to-hit-farmers

[13] Dawn, 2013. Low quality, shortage of pesticides. http://dawn.com/news/1030914/lowquality-shortage-of-pesticides.

[14] Dawn, 2013. Rangers to check wheat smuggling. http://archives.dawn.com/2007/12/28/ebr4.htm.

[15] Eicher, C.K., 2001. Africa's Un-finished Business: Building Sustainable Agricultural Research Systems. Staff paper 20001-10, Department of Agricultural Economics, Michigan State University. East Lansing, Michigan.

[16] FAO, 2004. FERTILIZER PRICES AND PROFITABILITY OF FERTILIZER USE $\mathrm{ftp}: / / \mathrm{ftp}$. fao.org/docrep/fao/007/y5460e/y5460e00.pdf.

[17] Feder, G., R.E.Just and D. Zilberman, 1985.Adoption of Agricultural Innovations in Developing Countries: A Survey. Economic Development and Cultural Change, 33(2): 255-298.

[18] Government of Malawi, 2000. Agricultural Extension in the New Millennium: Towards Pluralistic and Demand-driven Services in Malawi. Policy Document Lilongwe: Ministry of Agriculture and Irrigation, Department of Agricultural Extension Services.

[19] Haq, R. 2012. Road to progress: 'For a prosperous Pakistan, land reforms inevitable. http://tribune.com.pk/story/462947/road-to-progress-for-a-prosperous-pakistan-landreforms- inevitable/

[20] http://farmingpak.blogspot.com/2012_01_08_archive.html

[21] IRINEWS, 2009.PAKISTAN: Absence of land reform entrenches povertyactivists. http://www.irinnews.org/report/86319/pakistan-absence-of-land-reform-entrenchespoverty-activists.

[22] Jabbar, A and S. Mallick. 1994. Pesticides and Environment Situation in Pakistan, Working Paper Series \# 19. Pp 15-17.

[23] Kahlown, M.A. and A.Majeed, 2003. Water Resources in the South: Present Scenario and Future Prospect, Chap 2, pp 21-40.

[24] Khan, A.F. 2010. Can the role of middleman be eliminated? Website Link: http:// www.archives.dawn.com/archives/154876.

[25] Khwaja, N. 2013. Agricultural practices in developing countries. http://www.pakistantoday.com.pk/?p=289023.

[26] Kinsey, B.H. 1999. 'Land reform, growth and equity: Emerging evidence from Zimbabwe's land resettlement programme. Journal of Southern African Studies 25 (2): 173-96.

[27] Naeem, W., 2012.Fighting the feudal setup: Land reforms key to reducing poverty, empowering peasants, Daily Tribune, Karachi. Website link:http://tribune.com.pk/story/4612 32/fighting-the-feudal-setup-land- reforms-key-toreducing-poverty- empowering-peasants/

[28] Obaa, B., J. Mutimba and A.R. Semana, 2005.Prioritizing Farmers' Extension Needs in a Publicly- funded Contract System of Extension: A case study from Mukono District, Uganda. Agricultural Research and Extension Network. Network Paper No. 147. 
[29] Pakistan Today, 2013. Two nuclear power plants to be commissioned by 2016.WebsiteLink:http://www.pakist antoday.com. pk/2013/02/22/news/national/twonuclear-power-plants-to-be- commissioned-by-2016/

[30] Pakkissan, 2005. Government must stop rice smuggling to stabilise prices http://www. pakissan.com/english/ne ws/newsDetail.php?newsid=5941.

[31] Pakkissan, 2007. ws/newsDetail.php?newsid=14158.

http://www.pakissan.com/english/ne

[32] PARC. 1980. Crop ecological regions in Pakistan. Memograph. PARC, Islamabad. products is widening day by day. Available at www.pakissan.com.

[33] S.J. Malik, M. Mushtaq and M. A. Gill. 1984. Differential Access and the Rural Credit Market in Pakistan: Some Recent Evidence. The Pakistan Development Review, 28(4):111-129.

[34] Sadaf, S., S. Muhammad and T.E. Lodhi, 2005. Need for Agricultural Extension Services for Rural Women in Tehsil Faisalabad-Pakistan. J. Agri. Soc Sci. 1(3): 248251.

[35] Shah, N.A and U. Farooq, 2000. Post harvest loss: management and environmental conditions. PARC. cles/Post\%20Harvest\%20Loss.html

Website:http://www.parc.gov.pk/arti

[36] Sheikh, S.A., S.M. Nizamani, A.A. Jamali and M.I. Kumbhar, 2011. Pesticides and Associated Impact on Human Health: A Case of Small Farmers in Southern Sindh, Pakistan. Journal of Pharmacy and Nutrition Sciences, 1: 82-86.

[37] Shoukat, A., 2009. Privatization of Agricultural Extension System in the Punjab, Pakistan: A SWOT Analysis. PhD thesis, University of Agriculture, Faisalabad.

[38] Soomro, B. 2011.Pakistan: Cultivable waste land for agriculture graduates. http://technologytimes.pk/englishnews.php?title=Pakistan:\%20Cultivable $\% 20$ waste $\% 20$ land $\% 20$ for $\% 20$ agriculture $\% 20 \mathrm{~g}$ raduates.

[39] The News, 2012. Viral Outbreaks in Poultry http://www.thenews.com.pk/Todays- News3-103698-Viral-outbreak-sends- poultry-rates-soaring.

[40] The NEWS, 2012.Fish exports falling on post http://www.thenews.com.pk/TodaysNews-3-154134-Fish-exports-falling- on-post-harvest-losses-expert.

[41] The News, 2013. Pak Iran Gas Pipeline pact http://www.thenews.com.pk/TodaysNews-2-163575-Pak-Iran-pipeline-pact- precipitates-shift-in-foreign-policy.

[42] Tilman, D., K.G. Cassman, P.A. Matson, R. Naylor \& S. Polasky, 2002. Agricultural sustainability and intensive production practices. NATURE 18(2): 671-677.

[43] Tribune, 2012. Fertilizer sector wants gas in exhchage for price cuts in Pakistan http://paktribune.com/business/news/ Fertiliser-sector-wants-gas-in- exchange-forprice-cuts-10617.html.

[44] Tribune, 2012. Role of army urea smuggling. http://paktribune.com/business/news/Army-role-in-stopping-urea-smuggling-suggested4849.html.

[45] World Bank, 2003.Pakistan: Priorities for Agriculture and Rural Development. http://go.worldbank.org/KQ3CN5O0J0. 